\title{
The Sporting Image: A personal journey utilising history to develop academic inquiry and creativity
}

\author{
Iain Adams \\ International Football Institute, University of Central Lancashire, Preston, UK.
}

\begin{abstract}
In 1997, an optional third year undergraduate module, The Sporting Image, was developed for sports studies students in which they scrutinized the portrayal of sport in popular and high culture; including literature, film, TV, art and music. Fifteen years later, this module, now compulsory for Sports Journalism students, continues to examine the portrayal of sport and ways in which it has become an integral part of popular culture and resonates with values and standards specific in time and place. This paper describes the evolution of the module and its successes and failures in obliging both the lecturers and students to move outside of their comfort zones and engage with creative writing, poetry, music and the visual arts.
\end{abstract}

\section{Introduction}

In the late 1970s, I was engaged in my $\mathrm{PhD}$ research at the University of North Dakota when I noticed an interesting optional module being offered on the taught Master's programme by my Master’s degree supervisor, Bill Bolonchuk. This was called George Plimpton and Sport and seemed to be a radical departure for Bill, a hardnosed quantitative kinesiologist, so I attended the module. George Plimpton, a graduate of Harvard and Kings College, Cambridge, a close friend of Bobby Kennedy, editor of the influential literary journal The Paris Review, a CIA agent of note and occasional Sports Illustrated writer produced a number of books as he swam against Don Schollander, sparred with Archie Moore, golfed against Nicklaus and Palmer, quarterbacked for Detroit Lions and netminded for the Boston Bruins. ${ }^{1}$

With Bill, we discussed Plimpton's work in this new genre of participatory journalism and hypothesized about its impact on people's views of sport and the place of professional sport in American society and culture. I enjoyed the humour and self-deprecating manner of Plimpton's writing as he described the lived experience of entering new activities, often enabling the sport to "take you out of your skin, make your hair stand on end". ${ }^{2}$ Plimpton allowed me to identify with the experience and gain insight into what it takes to be a professional athlete and how 
people approach new sporting situations and create meaningful communities. The module influenced the way I thought about sport, the way it inter-connected with society and culture, and the way people interacted with sport, and therefore must have affected the way I worked in sports development, full-time and part-time, over the next twenty years across four continents.

\section{The Sporting Image}

In 1997, I was hired by the University of Central Lancashire to develop degrees in sports studies and sports management and with a tabula rasa, I wrote a third year module, The Sporting Image, which was designed to give me the opportunity to enjoyably develop my Plimpton inspired interest in literary and visual representations of sport and their impact on society and culture. From the very start, The Sporting Image was intended to consider not only the visual image but images sculpted or painted in words and music. The emphasis was to be on creative images rather than documentaries or newspaper reports. The overall aim of the module today remains the same as it was then, to scrutinize the representation and interpretation of sport in our culture, the ways in which sport has become an integral part of popular culture and how these representations and interpretations resonate with values and standards specific in time and place. Hopefully by the time the students complete the module, they will have a greater understanding of the relationships between sport and culture, how these relationships are represented in popular culture and how these created texts can work "in Quintessential fashion on emotions and feelings”. ${ }^{3}$

In the module we look at sport in feature films, cartoons, commercials, sculpture, ceramics, music, poetry, photography, novels, short stories, plays, sporting artefacts and how sport is represented in museums and galleries, specialised and general, local and national. One week session is in the archives of the National Football Museum in Preston where students are asked to select one artefact, research it and then lead a discussion on it in a following seminar. Some weeks are thematic, for example heroes, national and local identity, drugs, or racism are explored through their representation in the arts and through a variety of theoretical and conceptual stances seeking to understand what the representations meant in the imaginary world of the time of their creation and to draw parallels to audiences today. In other weeks, specific textual forms are studied, for example a session on fine art may concentrate on the representation of football in chronological order from the 1810 The Doonies 
versus the Croonies on New Year's Day by Alexander Carse to Peter Howson's Just Another Bloody Sunday.

As some of the Sports Studies students are 'top-ups', having completed their Foundation Degree or HND at a college, the academic background of some of the students is unknown. Therefore the first week sessions have always involved a quick guide to theories we think may be useful with appropriate readings, these readings include viewing Rocky IV as an 'in your face' case study of semiotics and metaphor. However, we stress each week that discussions can be grounded in any theory with which they are comfortable be it sociological, cultural, physiological, psychological, ethnographic, artistic or even mathematical. ${ }^{4}$ This multi-disciplinary theme continues throughout the module. As a Birmingham graduate from many years ago, I introduce Stuart Hall's 'four stages of communication' model early on to help the students understand that it is not merely the encoder or the message that is important. The students are sometimes asked to discuss Michael Brown's The Art of the Game without any information available other than a PowerPoint slide of the image on the screen and their own knowledge and experiences. Then they are shown images of Piero della Francesca's Resurrection and Andrea Mantegna's The Triumphs of Caesar with a layman's (mine) view of the symbology in the paintings. The students are then shown The Art of the Game again and given an overview of Cantona's career up to 1997 and Michael Brown’s background. The painting is re-discussed and we try to identify how the students' initial views of the painting fit into Hall's decoding classifications. Hopefully this experience that "the meaning is not in the text, but in the reading" carries through into the rest of the module and beyond. ${ }^{5}$

Over the last fifteen years the biggest changes are that the module has become compulsory on the sports journalism degree and has become a single semester module rather than year-long. Sadly the change to a single semester resulted in specialist weeks on posters, cigarette and bubble-gum cards, stamps, fine art, popular art, caricatures and ceramics being subsumed into more inclusive topics. The book club approach through which students studied two novels throughout the module was dropped and the one week dedicated to short stories has to suffice. In a similar vein, the three weeks dedicated to the relationships between music and sport were collapsed to one week. The music week seems to naturally follow the poetry session, which includes football chants, and examines an eclectic mix of songs and music associated with clubs, events and sports films, songs about specific athletes and 
teams, selecting music for exercise, and motivational choices of athletes. Also, specific film weeks disappeared and films are now assigned as preliminary 'readings' the week before specific themes. Mystery, Alaska is used before examining commodification and globalisation and Raging Bull adds to their interpretation of hero. Guttmann identifies that "popular fiction and film almost always celebrates the winners of sports contests while more ambitious novelists and film-makers ... all tend to tell tragic stories of athletic failure”. ${ }^{6}$ He notes that Hans Ulrich Gumbrecht in In Praise of Athletic Beauty recognized that spectators who rarely achieve heroism can easily identify with losers exhibiting human frailty.

In the 2008-2009 academic year, Clive Palmer joined the teaching team which led to a dramatic evolution in the form of assessment. Clive has a background in aesthetics and sport and actively encourages students to communicate their experiences and discoveries through writing. He postulated that in such a module it was not sufficient to make the students critically think about sporting issues and how these are portrayed through the media and in the arts, we had to get them to creatively communicate their thoughts, and then we had to assess the created communication. After discussion, I agreed that this would be an educationally stimulating thing to do and we asked the students in their final assessment to write a poem illustrating and illuminating their essay. This had to be included as an appendix but would not be marked. Pedagogically we thought this would be of value to the students through their shared experience of critical reflection on a sporting issue and its media representation, and then through experimenting with different writing styles which was followed by the development of a critical appreciation of their own work - was their poem good, bad or indifferent from the viewpoints of content, structure, theme, form and composition. Why not marked? Because I for one, was well outside of my comfort zone, who was I to judge whether the poem was good or bad?

\section{Poetry Please}

To support this endeavour we brought in John Lindley, a former Cheshire Poet Laureate, to run a workshop. The workshop gave the students some direction and freedom to start writing poetry and encouraged them to experiment with structure and form. As Clive soon observed the students were their own harshest critics and often their own perceived failure was actually the result of a lack of depth of knowledge and awareness - it was hard writing about the passion of being a Manchester United 
fan if you were not a Manchester United fan or even a football fan at all. Selfdirected research began to improve the poetry.

The resultant poems tended to be either intensely autobiographical evolved from the students' own experiences of sport and their feelings about sport or biographical of others' experiences. To our delight, several students whose overall grade point average was not sparkling, had obviously been inspired to actually research such events as the Hillsborough disaster, Smith and Carlos's protest, or develop their knowledge of local and national identity. With John Lindley's encouragement we decided to publish the poems in a book as a resource for the module. ${ }^{7}$ We ended up with over 65 poems in the book and some are better than others! Some students requested their poems not be included as they felt they had exposed too much of themselves in their poetry and obviously their wishes were observed. In addition, several students produced additional pieces of art simply for fun due to the inspiration of their poems; we used one student's oil painting as the front cover and another's ink sketching as the back cover. These visual images illustrated their poems; Samuel Van Gelder's oil supporting his poem entitled Fantaspursdom: ${ }^{8}$

I will always be Tottenham no matter how hard I try,

Changing now would be living a lie.

Every week we flock to White Hart Lane, The temple of experience, for victory or pain.

I sit in the stand with my Dad and my brother, Cheering on my team like no other.

From Sinton to Ginola, Berbatov to Postiga, Spurs shape my day, in a very big way.

Now play up 'Arry and keep us up, Or go one better and win us the cup!

Sam makes us think about the depth and continuity of loyalty to a club as players come and go, and the difference in approach by the players, who are making a living. Robert Hendry explored this concept in A Game of Three Halves possibly partly inspired by the American artist Ernie Barnes' acrylic and oil Sunday's Gladiators that we had discussed in class. ${ }^{9}$ 
A soaring coliseum where gladiators collide,

A theatre of mud where mundane misery rules supreme,

Could this rainbow be tribes at war?

No, no, just overgrown beings,

In a futile pursuit of happiness,

That will never come.

Ten workers toil for an artist to paint a masterpiece,

Eleven mercenaries take out their target,

What does it matter?

This could be Liverpool or Rome,

For this season at least, this is their home.

A flash of magic, a herd battering,

When the crowd roars, it sings,

It says this is our religion,

These are our people, our army

And our artist with the ball,

It's football, bloody hell.

Somewhat surprisingly some students always seem to choose to explore the political and humanitarian responses to sporting disaster and catastrophe with Hillsborough, Heysel and Munich commonly featuring. Leah Berry explored Munich in her poem A United Manchester City: ${ }^{10}$

The colours stretched red and blue

This is how we remember you

That cold night in fifty-eight

Lays aside the things we hate

A length of silence to honour those

Who died the night the runway froze

After long weeks editing the students' poems for this first book, it was obvious that we had allowed the students to develop informed judgements about the quality of their own and other's work and pedagogically the idea of assigning creative work seemed justified as valuable for student learning and leading them to challenge their intellectual and writing skills for later life. Clive finally convinced me to go the whole hog and we would mark the final creative piece of the students.

\section{Creative Writing}

To this end we set the 2009-2010 final assignment as "What If", a counterfactual creative short story and a supporting coda. The coda was to indicate where creativity departed from reality in the story and to lay out the underpinning 
theoretical or conceptual framework. We realised that we could not expect the creative work, the short story, to overtly include this framework and therefore told the students that the theoretical/conceptual section of the coda could be regarded in a similar manner to the foundation of a house being built; foundations that would be hidden once the house was completed. Martin Johnes describes a similar analogy made in a conversation with Dave Russell. ${ }^{11}$ The theoretical or conceptual framework that makes up these foundations is entirely the students' choice. This means that marking the assignments takes much longer than standard essays as occasionally students will use theories with which we are not familiar and we have to read around the subject before marking the paper.

We established an assessment strategy that involves a first assignment worth $25 \%$ which is a draft of the image and the coda. There is then a $5 \%$ viva in which students meet one-to-one with a tutor for 15 minutes. In essence this is a detailed feedback session with suggested readings and theoretical discussion. Initially this was not part of the assessment with Assessment One being worth $30 \%$, however students were not availing themselves of the one-to-one opportunity and so it was made an assessment and the stipulation put on that students had to attempt all assessment components or automatically fail the module. Assessment Three is worth $70 \%$ and is the final creative work and coda.

Some students are unhappy with this andragogical style and do not want to be responsible for selecting their own subject, researching it and identifying a suitable theory or concept. ${ }^{12}$ This seems to apply especially to weaker students who remain motivated by grades whereas the better students enjoy the freedom and become motivated by intrinsic satisfaction.

To help the students gain confidence in creative writing before tackling their 'What If' story, we invited Philip Caveney, a Royal Literary fellow, to teach a creative writing workshop. Philip did not have any great expectations for the outcome, as none of these students had ever tried writing fiction before and "it's not just something you can have a go at. It takes years and years of practice. Doesn’t it?” Later in the year as he began to receive the short stories themselves he "quickly realised that it was time to put in my order for a large slice of humble pie....Here were stories to delight and intrigue the reader...stories that thrilled and amused in equal measure, stories that explored the imagination of the writers, but remained easily accessible to all...here too was a valuable lesson for your truly; that writing is not 
exclusively the domain of the specialist. Given a little time and encouragement, talent can blossom in the unlikeliest of places.”13 Typical of the resultant student stories was Aran Donovan's Tunney vs. Dempsey - the short count which I think is worth including as it reveals the depth of research undertaken.

\section{Aran Donovan: Tunney vs. Dempsey - the short count ${ }^{14}$}

\section{...8 $8^{\text {th }}$ November 1978, 93 Palm Avenue, Palm Island, Florida.}

The bloated old man lies back on his sun lounger, Baccarat tumbler of moonshine in hand, watching the two naked blondes frolicking in his pool. He had acquired a taste for Minnesota girls during his St. Paul days. It's chilly for skinny dipping, but that's the way he likes them and he likes the effect of the chill; after all, they're his personal assistants. He's proud that he still distils the best moonshine in the country and still 'interviews' every girl seeking work in his brothels. He smiles to himself as he glances down at the Miami News’ sports headline “Gene Tunney dead at 80”. Sap, hadn't even made the front page, his mind wanders ...

\section{$\ldots 22^{\text {nd }}$ September 1927, Soldier Field Stadium, Chicago, Illinois.}

Boxing's biggest prize, the talk of the world; the greatest boxers to ever grace the ring, Gene Tunney, world champion, and Jack Dempsey, former champion. Everyone wants to see this fight. Soldier Field holds 61,500 people, but tonight there'll be over a 100,000. In barbershops, offices, factories and at shoeshine stands, confrontational discussions, one man says Tunney, the next Dempsey. "Tunney’s the champ; he’s gonna win”. "Dempsey wants it bad, he needs that belt, he's gonna prove himself a winner again.” It's a year ago yesterday that they previously met; Tunney out-boxed Dempsey and became the world champion. Today, Tunney may conclusively prove he's the best or perhaps Dempsey will gain revenge and retribution.

Nearly fight time; the stadium filling, 145,000 people cramming in for the big one, it'll be an epic, monumental. People will say "Where were you when...” Well, tonight, they're all here, politicians, entertainers and gangsters. Secretary of State Emerson moves towards his seat, his entourage includes US Solicitor General Mitchell and Chicago Mayor Thompson. They pause as Al 'Scarface' Capone rises, "Mr Secretary, Mr Solicitor-General, this is Al Capone” says the mayor. The men 
shake hands, "I know Al” says Mitchell to the mayor, "I was his lawyer in St Paul before Washington called.” Capone smiled, “follow my advice gentlemen, you may be Tunney men, but put money on Dempsey, Dempsey’s been workin' hard”. “Thanks for the tip” frowns Emerson leading his group off. Mitchell pauses at the next aisle, whispers briefly to an aide who scurries off. Tex Rickard, the promoter, moves to the centre of the ring, "Ladies and Gentlemen, welcome to tonight's main event...”

Tunney appears with championship belt resplendent. Appreciative noise fills Soldier Field, 145,000 fans clapping and shouting. Tunney boogies into the ring, a quick sliding shuffle from left to right as the crowd chants “champ, champ!" Dempsey emerges, the noise is painful; Chicago loves Dempsey, the working class brawler. His magnanimity in last year's loss has moved him to sainthood. His name pulsates round as the fans stomp and scream, the juddering and throbbing resonate the ring ropes violently. Dempsey skips down the red carpet, bounces up the steps and into the ring, fit, energetic, ready to go, this man is prepared. The fighters stare, the pre-fight stare-down, who will look away first. The Manassa Mauler glares into, and through, The Fighting Marine. The referee, Barry, stands between Tunney and Dempsey. "Both you boys have received a book of rules of this boxing commission. They are the rules under which you are going to fight. Now I want to get one point clear. In the event of a knockdown, the man scoring the knockdown will go to the farthest neutral corner. Is that clear?” Tunney nods sharply, Dempsey bobs his head once. Then Barry continues, "in the event of a knockdown, unless the boy scoring it goes to the farthest neutral corner, I will not begin the count, OK, LETS GET IT ON!!!”

Round 1 - Dempsey charges out, older in years and much older through life, he wants this over. He throws a right, missing as Tunney glides back, and then slides forward to sneak in a jab to Dempsey’s body, first points. Dempsey scores with a left and shoots out a vicious straight that finds only air. Tunney successfully jabs and takes a half step back as Dempsey rushes forward, a hard straight left into his face stops Dempsey in his tracks, an overhand right to his head drives him back. Tunney sashays forward to jab and Dempsey catches him with three short hard brawling swipes. The crowd roars its approval, “Get in there, Jack!” Tunney grimaces and coolly steps closer and pinions Dempsey's arms in his vice-like grip. Dempsey growls in rage and struggles to get free. "Break!” commands Barry. They step back, 
Tunney skips in and scores with another jab. The bell signals the end of round one, and it's gone Tunney’s way.

Round 2 - The champ's in control, circling the ring, Dempsey chasing; the big 20 foot ring not to Dempsey’s liking. Dempsey swings erratically and unpredictably as if his body and brain are out of sync, he hasn't landed a clean punch yet. Tunney, the shrewd tactician, weaves away waiting for an opening. Abruptly he fires a blistering left to Dempsey’s body. Dempsey steps back, settles into his familiar crouch and then presses forward shooting hooks at the fast-moving target. Tunney dispatches a stinging straight left to Dempsey's jaw stopping the charge, Dempsey tastes and swallows blood. Then a shower of short jabs from Tunney confuses Dempsey who covers his face and absorbs the punishment. As Tunney pauses, Dempsey moves close and for 10 seconds he is landing head shots, jabs, hooks, body shots. But Tunney steps in and wraps his arms around Dempsey pinning his arms to his side until the referee forces them to break. They swing around sparring until the bell rings, “Dempsey’s trying, but it’s going our way” enthuses Emerson to Mitchell.

Round 3 - The fighters charge out; Dempsey tries to close, get Tunney into the maul zone for a few quick combos. "Keep on crowding him Jack, hold him close” yells ‘Boo Boo’ Hoff sitting by Capone. Tunney won’t oblige and keeps boxing from a distance; he's spent too long analysing Dempsey to mix it in close. Tunney looks for the openings, building points. Dempsey tries left hook, right hook and a jab, but its thin air. Another rush, another straight left into his face, a cut opens above his right eye. “That's another round to Tunney, this fight's going the same way as the first” laughs a woman loudly.

Round 4 - Dempsey wants to finish this and comes out to land that killer blow. He crowds forward but is again stopped by Tunney's ever ready straight left, an overhand right to Dempsey's head shoves him back. And then they're both standing in the middle of the ring, trading blows; Dempsey jabs, Tunney uppercuts, Dempsey uppercuts, Tunney jabs. Dempsey moves in like a barroom brawler. "Tie him up like a bag, Genie” screams Emerson from the front row willing Tunney to use his steel band-like arms to pinion Dempsey again. Tunney obliges skating in and holding Dempsey, forcing another break. The crowd is roaring, screaming, going nuts. The bell rings and the referee splits them again. Tunney's fans are ecstatic, their man's streets ahead. 
Round 5 - The crowd stands as the bell rings, wild shrieking and screaming as Tunney backpedals, Dempsey leading with a wild right trying to get in close; Tunney ducks, but the right was a fake to disguise a rush. A booming straight left into Dempsey's face rocks him backwards, his left eye begins to shut, another overhand right to the jaw piles up the points. "Atta-boy Genie, get some combos in.” For long seconds the two stand toe to toe Dempsey swinging and Tunney blocking. The crowd are still screeching at the bell.

Round 6 - Another stupefying roar as the round opens, but the noise subdues, the pace is slower, the fighters are tiring, Dempsey breaks through and lands two hard blows, again Tunney is forced to step in and bind Dempsey's arms to his sides; Dempsey scowls and struggles. “Break!” Tunney dances away, Dempsey follows and leads with another right; Tunney responds in kind, Dempsey jabs, slips another jab but receives a hard overhand right to the jaw, it's beginning to swell. Several sharp blows follow on, points accumulating in Tunney's favour. "Jack got a couple of doozies in there” cries 'Boo Boo' as the bell clangs.

Round 7 - Tunney presses forward, looking fresher, Dempsey advances and Tunney retreats, but is momentarily constricted by the ropes in the corner. Dempsey seizes the opportunity and launches a combination of punches, two rights, two lefts to the chin, Tunney staggers disoriented; “This is it Jack, FINISH HIM”. Dempsey suddenly metamorphoses into the Dempsey of old, the blows he has been dreaming of unleashed as a flow of four catastrophic punches, left-right, left-right; crashing the champ to the floor. Tunney grabs the middle rope to stop the world spinning, shaking his head. He hears the timekeeper intoning "ONE...TWO”, the referee shouting "Go to a neutral corner, Jack!" “THREE.” The referee moves away pushing Dempsey towards the neutral corner, "FOUR", the referee is back above Tunney and Tunney hears him join the timekeeper's beat "FIVE...SIX," “Five! The referee started his count at five, that's not fair" shouts somebody in the crowd. "SEVEN." "How can he start his count on five” exclaims another indignantly. "EIGHT,” Tunney gets a knee under himself balancing with his right glove on the floor, "NINE", it's all in slow motion, “TEN”.

The stadium erupts. "Jesus, that's an outrageous end to a brilliant fight” moans a Tunney fan. “And It's spoilt by an innumerate referee who can't count” yells his wife. Dempsey, glassy eyed, is led by the referee to the middle, cries of "fix! Fix! FIX!" come from sections of the crowd. "This is madness, a controversial end to such 
a magnificent fight. No one can take away this victory from Dempsey, he was magnificent tonight, but what a horrible way for Tunney to lose, a short count” notes a journalist. Rickard steps into the spotlight, “Ladies and Gentlemen, I give you your new world heavyweight champion, Jack 'The Manassa Mauler' Dempsey, the first man to re-capture the heavyweight title of the world”. Dempsey's arm is hoisted into the air as the title belt is fixed around his waist.

Rejuvenated old legs carry Dempsey to Tunney’s corner, “Gene, you were best. You fought a smart fight, kid. That's it for me, I retire right now!” He hoists Tunney's arm aloft to a roar of approval from the hordes. Emerson makes his way out, Mitchell pauses as a runner gives him a package, moving past Capone he briefly stops and shakes his hand ."Your boy lucked out tonight; don't forget to pay your taxes on the winnings!” He glances back as Emerson leads them off; Capone catches his eye and mouths "You owe me one."

\section{$\ldots 8^{\text {th }}$ November 1978, 93 Palm Avenue, Palm Island, Florida.}

The old man chuckles at memories, only seven, generally comfortable, years in prison. Those bastards Elliot Ness and Frank Wilson tried to put him away forever, but Mitchell, Attorney General by then, threw out most of the prosecution evidence. He paid his dues. The very thought of Ness and Wilson brought on chest pain, Jesus, crushing pain. Through gritted teeth he wheezes "Holly, Vicky". They rush to him. Suddenly he is floating above watching the two naked girls performing CPR on him, Doc Phillip's taught them well. Crash teams like that would have improved Emergency!'s ratings. It's been a good life, if this is death, it ain't so bad.

.... $9^{\text {th }}$ November 1978, 93 Palm Avenue, Palm Island, Florida.

'Scarface dead at 78' screams the front page of the Miami News.

Aran's accompanying coda illustrates that he has not changed the fight at all but develops his story around the personages who attended the fight and the rumours that Al Capone had tried to fix the fight. The authorities replaced referee Dave Miller with Dave Barry at the last minute due to the stories; both boxers were eventually inaugurated into the Boxing Hall of Fame. He changes Capone's death, in reality cardiac arrest after a stroke, for dramatic effect. 
Sometimes hints given in the viva are insufficient. One What If? story concerned Duncan Edwards surviving the Munich crash and Bobby Charlton being a fatality. In the proposal and viva, the student laid out an idea for dialogue when Edwards becomes the BBC Sports Personality of the Year. It was suggested in the viva that he might try to put the dialogue into the vernacular and to check the birthplace and background of the characters. Sadly the student lost some points for identifying Dudley as a southern suburb of Manchester, despite the obvious work in carefully putting Edwards' words into Mancunian. The story itself was interesting so some time was spent by an editor carefully translating Edwards' words into the correct Black Country dialect for inclusion in that year's book, the student had long since disappeared after graduation.

\section{Into the visual}

In 2010-2011, we decided to really move out of my comfort zone and set a very open assignment, 'A visual image of a specific sports theme or topic'. We gave some examples of the sorts of themes or topics that could be explored; 'Drugs at the Olympics', ‘Armstrong: Living strong', and 'Shankley: Liverpool times'. As the previous year, a supporting coda would provide a theoretical or conceptual spine giving the work an academic base as well as laying out the underlying narrative.

Once again, we decided that the students should be supported by a workshop and invited in Val Sellers, a retired PE teacher who has researched and written extensively on aesthetics and sport. This workshop provided students with an introduction to some processes of abstraction in art and about form and content in art. The resulting book of student work includes the supporting coda giving some insight into the students' inspiration for creating their final image. ${ }^{15}$

Risa Tatehata's Outrun by the truth and reality shows Ben Johnson winning the 100 metres gold at the 1988 Seoul Olympics in a new world record of 9.79 seconds but "the shadow of Ben Johnson clings onto his body, a metaphor for the moment when the reality of his inner truth grabs him and disconnects him from his career". She further explains that the image is based on a photograph of Johnson crossing the finishing line and the flame-like shadows are creeping up "to pull him back from undeserved victory and down into the hell of reality."16

Jack Thompson provided an alternative view of the Olympic 100 metres with 


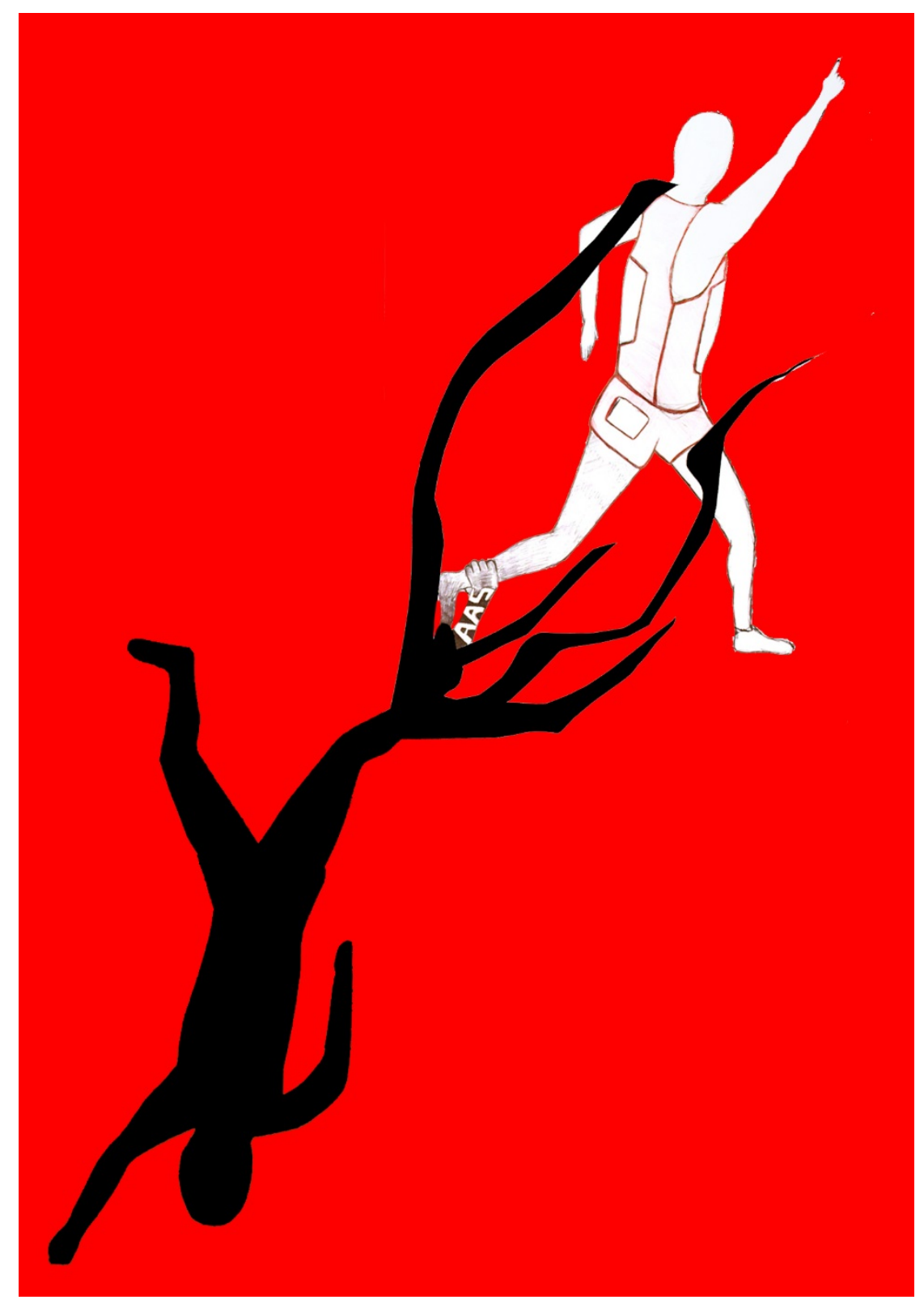

Figure 1. Rita Tatehata, 'Outrun by the Truth and Reality'. Source: SSTO Publications. All rights reserved by Clive Palmer, Risa Tatehata and Iain Adams.

his Bolt from the darkness. It portrays his hopes and aspirations for man twenty years on from Johnson's infamous run. ${ }^{17}$ In his coda Jack explained that Usain Bolt is seen bursting from the shadows of being very good into the spotlight of being the very best, moving him up to Stage Three of Klapp's hierarchy of hero worship and into the 'high hero, high celebrity' bracket of Shuart's 'celebrity-hero' matrix. ${ }^{18}$ Bolt is illustrated as having the flamboyance and the style to show that he not only has the “common qualities like courage and willpower but also specific national and social characteristics". ${ }^{19}$ Thompson depicts Bolt as almost the saviour of athletics, the 
shadowy tendrils of drugged performance are not attached to him, and they are left behind rather than clinging to him, waiting for him to slow down, and then envelop him and drag him down. In gaining gold in Beijing in a new world record of 9.69, he has moved athletics from the dark place identified by Pampel, and illustrated by Tatehata, back into popularity and credibility. ${ }^{20}$

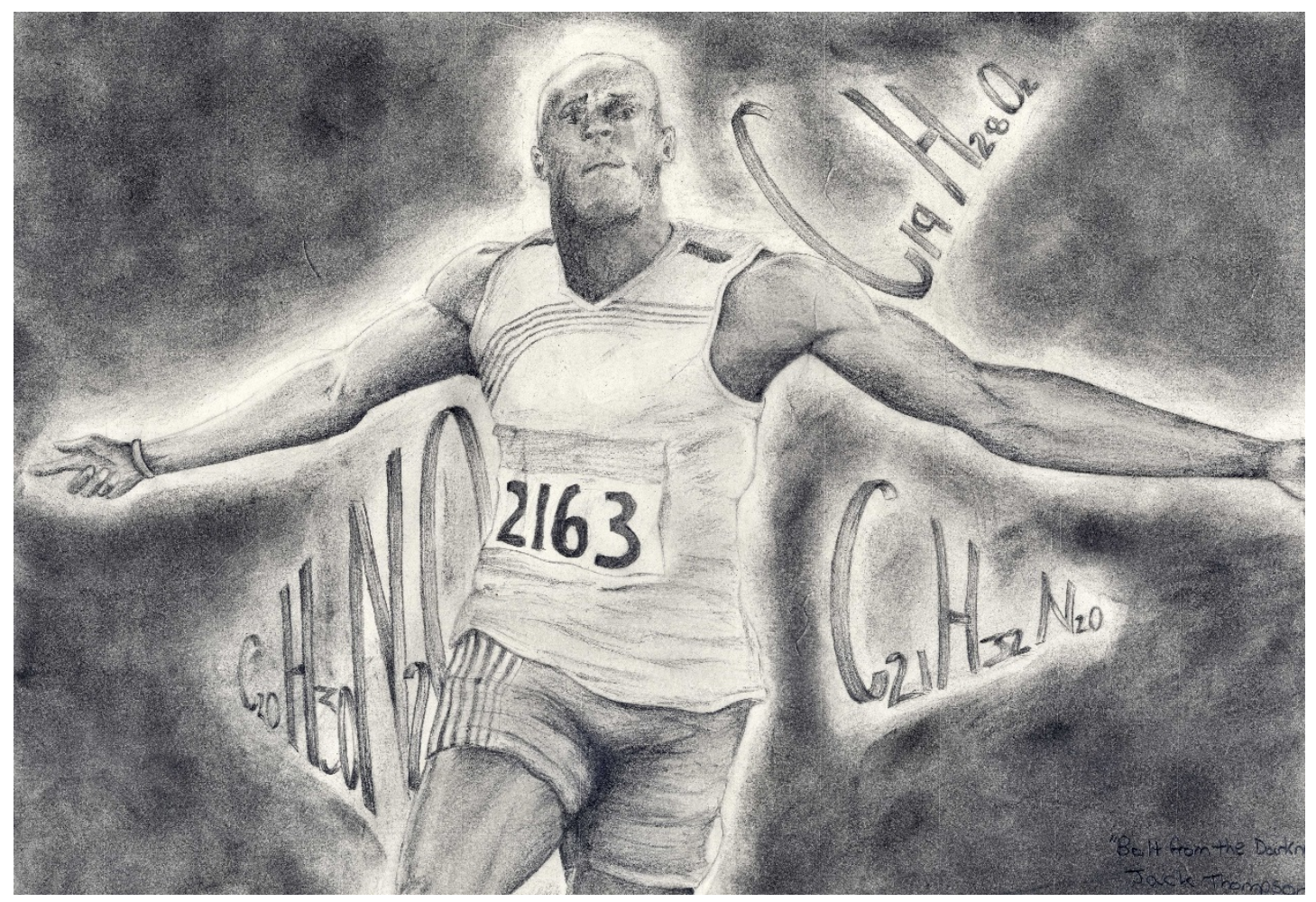

Figure 2. Jack Thompson, 'Bolt from the Darkness'. Source: SSTO Publications. All rights reserved by Clive Palmer, Jack Thompson and Iain Adams.

Nicholas Hart's FC Barcelona: Mésqueun club (more than a club) explores the important role this club has played in the culture and traditions of Catalonia. ${ }^{21}$ The phrase, Mésqueun club, was coined by the club’s president, Narcís de Carreras in the late 1960s although the sentiment goes back to the founding of the club in 1899.Throughout its history, Barcelona FC has been a focal point of Catalan identity and in the Franco years, 1936-1975, supporting 'Barça' was a less risky way of demonstrating identity than joining the clandestine anti-Franco movement. Today 'Barça' is still a symbol of Catalan independence and pride and is unusual in world association football being owned and controlled by its fans. The fans demand certain levels of behaviour and performance from their players and also expect a certain style, ‘tiqui-taca' (tiki-taka), short passing with high levels of movement. The players 
in the image are those renowned for the creation and execution of this style, many are graduates of La Masía, the youth training centre. The fans look up to these players, Lionel Messi, Andrés Iniesta, Johan Cruyff, and Pep Guardiola, colour drawing attention towards the players and fans to emphasis interaction and relationships. The current players are towards the front and more focussed as the previous players recede into mythology.

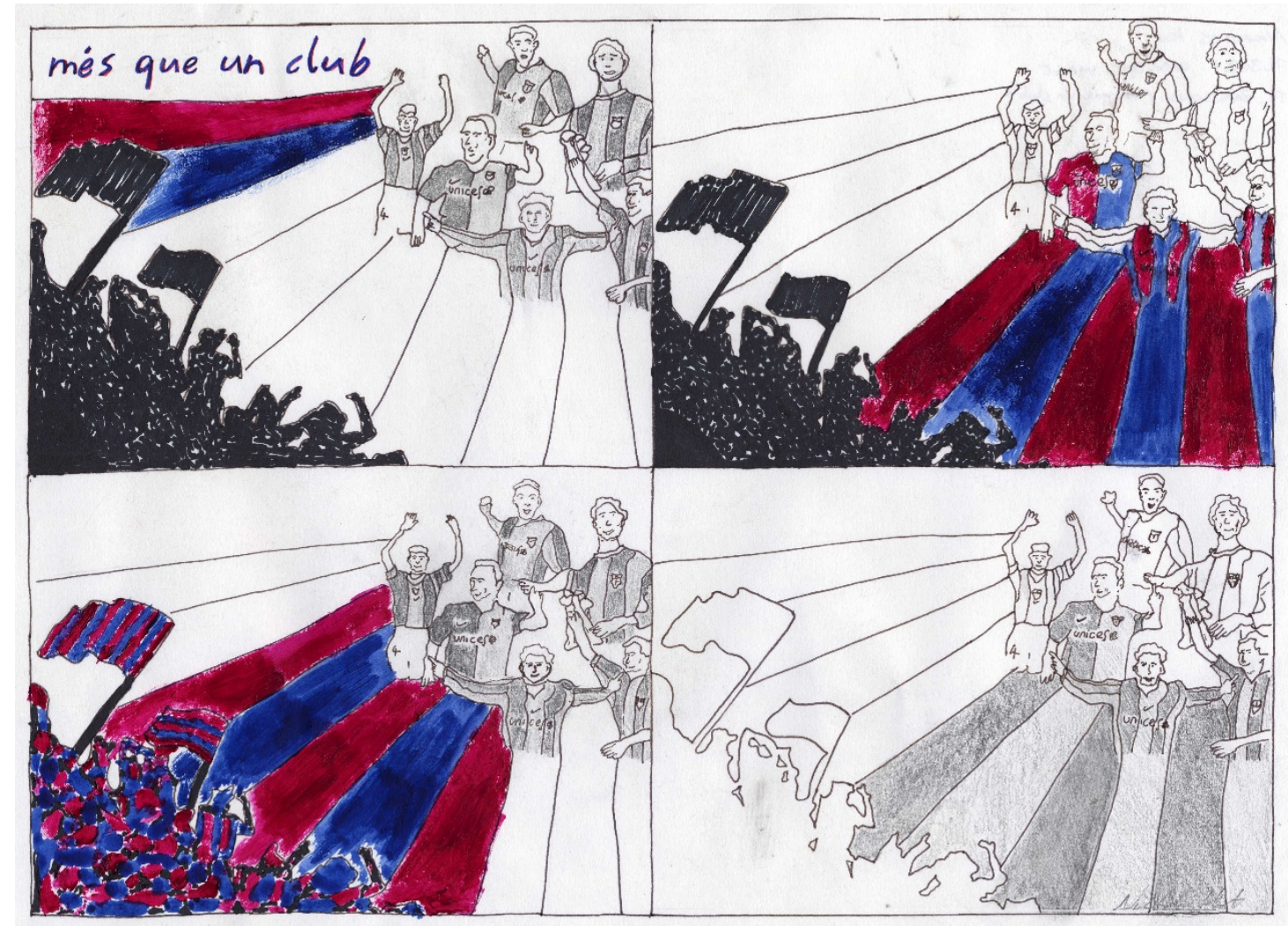

Figure 3. Nicholas Hart, 'FC Barcelona - Mésque un club’. Source: SSTO Publications. All rights reserved by Clive Palmer and Nicholas Hart.

Alex Blackall's Flash was inspired by a moment that is becoming incorporated into one player's mythology. The image is grounded in the concept of movement and what can be experienced in the briefest moment of time. ${ }^{22}$ His coda explained that no photo editing software was used and he simply experimenting with speeds of running with a flashlight facing towards the camera and different camera settings. The moment recreated is David Beckham's penalty against Argentina in the World Cup in Japan in 2002. For Blackall, this penalty had an aesthetic quality that made it a beautiful moment that he replicated in the brilliance of light. Flash is a metaphor, a flash of brilliance that might attract our attention in sport as long as it succeeded and 
we have not blinked or looked away. He uses phrases from the live TV commentary to develop his narrative of the importance of this event for the player, who had been sent off against Argentina in 1998, and for England fans at that time. His choice of a park pitch is to remind us, the viewer, of our childhood when we would re-enact great moments and Preston's Deepdale stadium in the background reminds us of Beckham's time as a Preston player in 1995. The park pitch also removes Beckham’s goal from the glare of the media and 'stadia hype' letting the goal stand alone as a beautiful moment of football brilliance. But the reality of a goal at this level is alluded to by Beckham's number going up in lights to the right of the image.

Patrick Watson contrasted the showbiz world of professional soccer with the stark under-representation of grass roots sport in the media with his oil-based pastels image Grass Roots. ${ }^{23}$ Although grass roots activity underpins most sports from

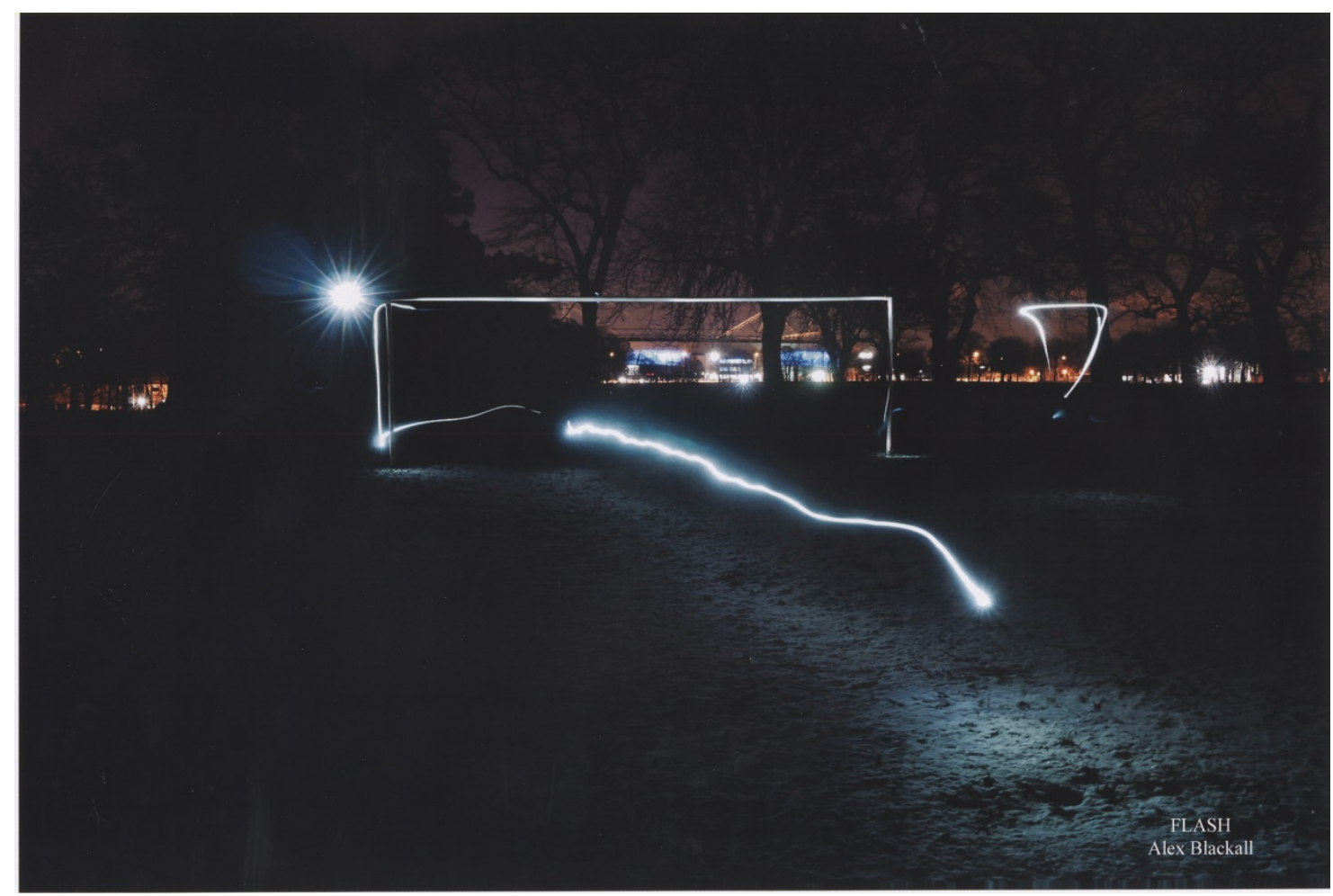

Figure 4. Alex Blackall, 'Flash'. Source: SSTO Publications. All rights reserved by Clive Palmer and Alex Blackall.

athletics through to yachting, football is used in the image because it is the United Kingdom's most followed sport and England is the home of the Premier League, Europe's most profitable sporting league, and where grass roots football receives less funding than anywhere else in Europe. Here the international star gladiator entertains the masses filling the wallets of the owners and administrators; supported by the 
roots whilst simultaneously crushing them beneath his feet, a metaphor for the money squeezed from the roots by the professional game and not returned especially to the poorer nations of the world. Patrick wanted to manufacture the roots from entwined links of pound signs but could not get a satisfactory result.

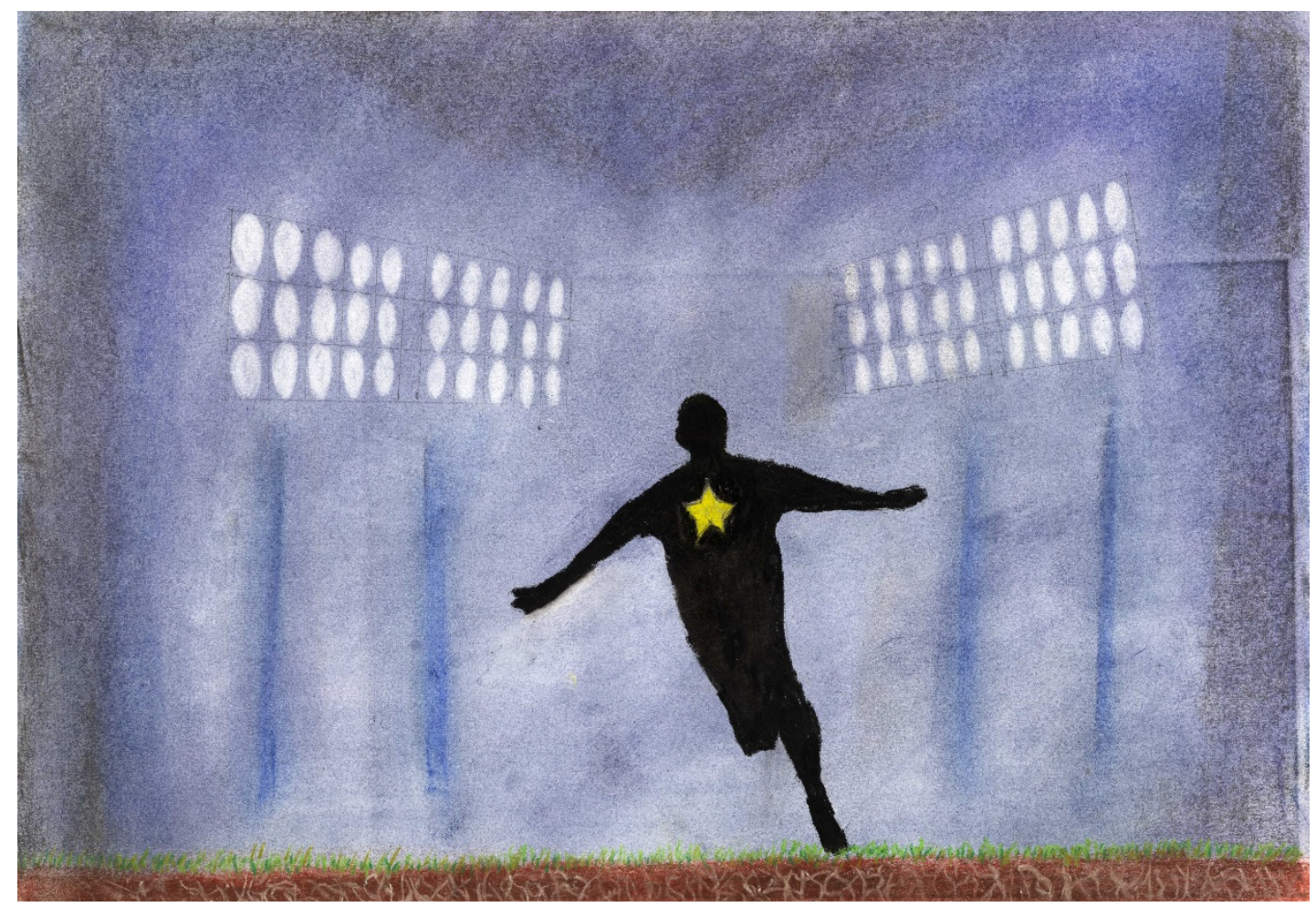

Figure 5. Patrick Watson, 'Grass Roots'. Source: SSTO Publications. All rights reserved by Clive Palmer, Patrick Watson and Iain Adams.

Michael Roberts, born in Derry, used Kofi Annan’s 2010 statement on sport to revisit the British government's attempts to use sport in Northern Ireland to bring the Catholic and Protestant communities together. Annan, the former Secretary General of the United Nations, stated in a speech in Dubai that "sport is the universal language, understood from Milan to Manila, from Montreal to Montevideo. It engages and brings our world together in a way few, if any other activity (sic), can manage. Sport has an almost unmatched role to play in promoting understanding, healing wounds, mobilizing support for social causes, and breaking down barriers.”24 Roberts' image Sport, religion and division in Northern Ireland centres on Maurice Harron's 'Hands across the Divide' statues which he has moved from their location at Carlisle Circus roundabout at the Craigavon Bridge in Derry to a gap in the Peace line that separates The Fountain and the Bishop Street areas and helps to prevent violent confrontation between the two communities. ${ }^{25}$ Roberts has armed the statues 
with each other's sports equipment with which they reach out to each other across the divide, symbolically offering to participate in each other's sports. This symbolic offering to play each other's sport symbolises overcoming the potential wedge of sport; "sport can reflect and even exaggerate divisions and this tends to the case in Northern Ireland" where sports were, in the main, played solely in their native cultural settings. ${ }^{26}$ Roberts has also moved two well-known murals from their positions in their community heartlands, these are to give a feeling of the historic ideology of the separate communities. The sky is layered red symbolising violence with streaks of United Nations blue giving pictorial play to Annan's hopes. The wellknown peace activists Nelson Mandela and John Hume look on with the European funded Peace Bridge between them, symbolizing togetherness.

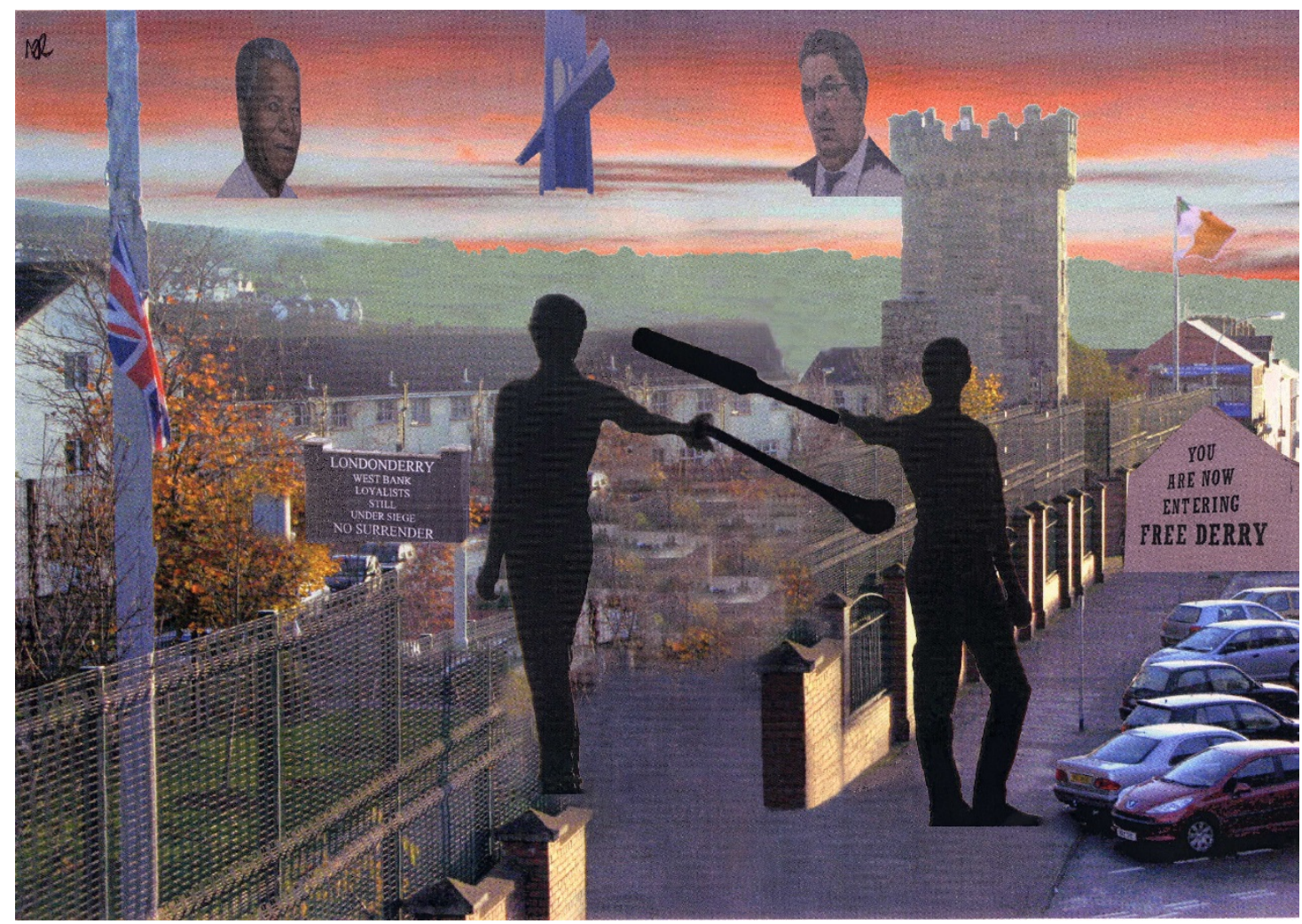

Figure 6. Michael Roberts, 'Sport, Religion and Division in Northern Ireland'. Source: SSTO Publications. All rights reserved by Clive Palmer, Michael Roberts and Iain Adams.

\section{Reflection}

Nearly every year, the module provides us with a range of marks, from single digits to the nineties. These marks usually indicate the degree to which students engage with the module and seek to find an assignment topic that interests them. To this end, 
we strive to provide very open assignments, a practice which unfailingly unnerves some weaker students. The assessment for 2011-2012 was 'Citius, Altius, Fortius: Eugenio Monti: Unsung hero of 1964' in which the student had to provide an image of either an unsung or a forgotten hero from an Olympic Games supported by a 1,000 word coda. The students were to replace Eugenio Monti with their own choice of an unsung or forgotten hero and replace 1964 with the relevant Olympic Games, summer or winter, or Paralympics. The image could be produced via poetry, short story, music or visually. In the first seminar which focussed on the assignment brief, a group of sports studies students stood up and left, it's not compulsory for them, so I assume they transferred to another optional module well within their comfort zone, another essay or report.

Module Evaluation Questionnaires (MEQs) are diverse in their feedback to us. Most dissatisfaction centre's on the fact that not every lecture is overtly relevant to the assessment and is therefore "pointless". Some students express dissatisfaction that the module does not focus on developing "English writing skill” or "microphone techniques" and the skills and knowledge developed are not especially "handy to journalists". We still try to get all of the sports journalist students to recognize the place of sport in a wider history and to examine how sport is represented beyond the who, where and when. Aran Donovan was fascinated at how much boxing was intertwined with other aspects of early twentieth century life in America once he went beyond the back page match reports. It was with some degree of smugness that during the feedback session of 2011-2012 we pointed out that The Sunday Times had just started a '100 Greatest Olympic Moments' series which had already featured several of the forgotten heroes that students had chosen; no doubt the editor had set his journalists a similar task to the one we had set although restricting them to written communication. However, a far greater number of students enjoy the concepts developed and one wrote on his MEQ "I got fed up with my whinging colleagues who couldn't rise to the challenge of the course". Another noted the assessment "was quite awesome, especially the thinking behind it” and this was the highlight of his journalism degree. One said "this was an exceptionally challenging module which forced me out of my comfort zone". Yet another "this was the hardest work I have done since GCSE's, I look at sport in different ways and will be a better journalist for it”. Sometimes we receive emails from past students who apologize for the poor MEQs that they left us and explain how the 'stuff' they learnt in The Sporting Image 
has since proved invaluable in the real world. Fortunately, we have received unqualified support from the Sports Journalism course leader, Charles Lambert, and constructive advice from external examiners, particularly Mike McGuinness of Teesside University who coincidently provided one of the background readings for the music session. ${ }^{27}$

In recent years, our belief in the module has been buttressed by the increasing number of papers on creative work and sport at academic conferences and in journals as well as dedicated academic texts. Of special interest was the 2009 conference The Visual in Sport at the University of Bristol and its resultant 2011 special issue of The International Journal of the History of Sport edited by Mike Huggins and Mike O' Mahony and the 2009 special issue of Sport in History on 'Sport and Literature' edited by Jeffrey Hill and Jean Williams.

Each year in the module induction, I ruminate with the sports journalism students that through their weekly interpretation of the visual and literary texts, and the testing of their interpretations against the interpretations of others, they may enrich their future newspaper reports, radio broadcasts and TV documentaries, which Guttmann points out "are merely interpretations of reality, to be tested and evaluated in the context of other interpretations". ${ }^{28}$ As Ian Mortimer commented "to understand your own century, you need to have come to terms with at least two others."29

The experiment in publishing books of the students' work as a resource for the next generation of students has proved popular. Often prospective sports journalism students visiting on open days ask us whether we will still be publishing their work if they come to the university the following year. Occasionally a student tells us the only reason they are coming to our university is because The Sporting Image was mentioned by a journalist on their local newspaper when they were there on work experience. They were told that The Sporting Image encouraged research into previous chapters of specific events and by understanding and reinterpreting the past it helped make sense of the story they were working on and provide alternative views, thus enriching their story. ${ }^{30}$

Probably the most excitement for us is generated by the students who are motivated to go that step further than merely getting a pass and create something of which they feel proud, something in which they invest part of themselves. A great satisfaction is the delight some students have in achieving grades far higher than they normally do; we have found that some discover a new sense of confidence in their 
reasoning when allowed to make a bold statement in something other than a traditional academic essay or report.

Even fellow staff get involved; several mentor and edit with us. In 2011, Paul Gray, Head of Outdoors was 40 and decided to participate in some performance art, cooking 40 omelettes over 12 months in 40 different adventurous or unusual settings with the performance accessed by YouTube and a large textile Omelette in Pan as a permanent office decoration. Clive felt that we were being prevented from doing all of the mentoring, editing and real stuff that was important for us by the unstoppable momentum of time, and so he produced a painting, 20.09, representing the unstoppable momentum of time. ${ }^{31}$ This dominates his office, where facilities management had put a real clock.

At a person level, The Sporting Image has moved me away from publishing in The International Journal of Aviation Safety and Perceptual and Motor Skills to joining 'The British Society of Sports History', timorously moving from attending their conferences, to presenting papers and finally submitting research papers to sports history journals. Historians are initially a scarily well-read and intelligent lot. In 2011, completing the assignment given to the students, I attempted my first art work since primary school, a collage, 'Dunc' and Ken: Hero and villain? which portrayed the reputations of Duncan Edwards and Ken Rayment, the pilot killed at Munich. Rayment, a World War II fighter ace, mentioned in dispatches and also awarded the Distinguished Flying Cross, is commonly incorrectly remembered as a villain who killed a hero, Duncan Edwards, through negligence. ${ }^{32}$ However, Leah Berry's research for her poem had revealed the real cause, a frozen runway with an incorrect snow/slush depth report given to Zulu Uniform's flight crew and a political cover up of the truth.

The Sporting Image was not designed as a sports history module, but the very fact that lectures, seminars and tutorials examine works that exist means that we are dealing with history and students faced with creating images whether literary or visual tend to seek inspiration in the past much as war artists of the late nineteenth century often used previous conflicts such as the Napoleonic wars to express their concerns and interests of the day. In many ways The Sporting Image is truly a 'sport studies' module requiring a multi-disciplinary approach to literary, aural and visual texts. After 15 years, The Sporting Image remains challenging and inspiring to me, there is intense satisfaction in sitting in the garden with a cold bottle of Liefmans 
cuvee-brut in early August after receiving Clive’s final email “OK, it’s done, it’s put to bed, gone to the publishers”. Zoe Horton, a sports studies student reflected on art in her poem What is art?

Art is the future, art is the past,

Enabling collective memory, images that last,

What defines 'good art' is hard to say,

It may be personal and could change from day to day.

"This particular painting that you see",

"depicts sport”,

"football",

"from a time in history".

It's a snapshot, a fragment in time,

Post-war northern England, footballers, smoking chimneys and railway

line,

Affected by war and industrial times,

Their works' teams differentiated by the colour of their lines.

A race some may say,

Nothing has changed, even today,

The politics, the issues, the national unrest,

The English, the British, still globally the best.

The message is not that clear what he is trying to say,

But the resilient footballer he successfully portrays,

Art can say so much, there's no doubt about it,

The artist's intention? For you to enjoy it? ${ }^{33}$

\section{Acknowledgements}

I am very grateful for the encouragement of the editor and the two anonymous referees for their reflective and constructive reviews.

\footnotetext{
${ }^{1}$ George Plimpton's sport books include Out of My League, Paper Lion, The Bogey Man, One More July, Mad Ducks and Bears, Shadow Box, Open Net and The Curious Case of Sidd Finch (a novel). For an overview of Plimpton's career in Paris see Cummings, 'An American in Paris'.

${ }^{2}$ Tomlinson, 'Taking the (Sea)Biscuit?', 160.

${ }^{3}$ Ibid, 159.

${ }^{4}$ One Combined Honours student in Maths and Sport Studies used Pythagorean theory to analyse 'The Village Ba' Game' by Alexander Carse.

${ }^{5}$ Hart, Understanding the Media, 60.

${ }^{6}$ Guttmann, 'Does Clio Need Help', 106.

${ }^{7}$ Palmer, The Sporting Image: Sports poetry.

${ }^{8} \mathrm{lbid}, 32$

${ }^{9}$ Ibid, 9.
} 


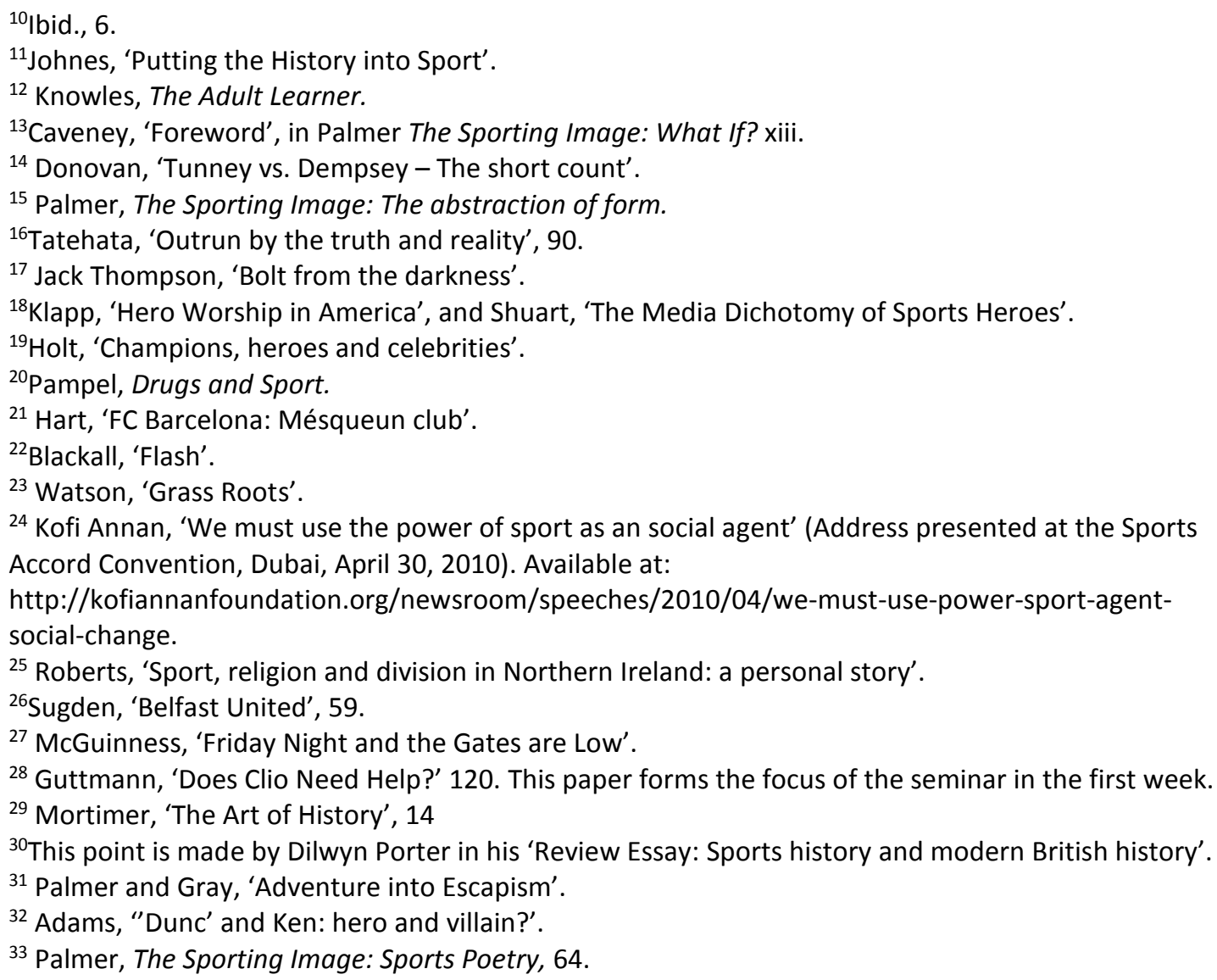

\section{References}

Adams, Iain. ' 'Dunc' and Ken: hero and villain?'. In The Sporting Image: The abstraction of form, ed. Clive Palmer, 128-135. Preston: SSTO Publications, 2011.

Blackall, Alex. 'Flash'. In The Sporting Image: The abstraction of form, ed. Clive Palmer, 32-35. Preston: SSTO Publications, 2011.

Cummings, Richard. 'An American in Paris: How George Plimpton waged the literary cold war'. The American Conservative, (February 16, 2004): 21-22.

Donovan, Aron. 'Tunney vs. Dempsey - The short count'. In The Sporting Image: What If, ed. Clive Palmer, 249-257. Preston: SSTO Publications, 2010.

Gumbrecht, Hans Ulrich. In Praise of Athletic Beauty. Cambridge, MA.: The Belknap Press, 2006.

Guttmann, Allen. 'Does Clio Need Help? A plea for a more extensive use of literary and visual texts', Sport in History 28, No. 1 (2008): 104-122.

Hart, Andrew. Understanding the Media: A Practical Guide. London: Routledge, 1991.

Hart, Nicholas. 'FC Barcelona: Mésqueun club’. In The Sporting Image: The abstraction of form, ed. Clive Palmer, 36-39. Preston: SSTO Publications, 2011.

Holt, Richard. 'Champions, Heroes and Celebrities: Sporting greatness and the British public'. In The Book of British Sporting Heroes, 12-13. London: National Portrait Gallery, 1999.

Johnes, Martin. 'Putting the History into Sport: On Sport History and Sport Studies in the U.K'. Journal of Sport History 31, no 2 (Spring 2004): 145-160. 
Klapp, Orrin E. 'Hero Worship in America'. American Sociological Review 14, no. 1 (1949):53-62.

Knowles, Malcom S., F. Holton III Elwood, and Richard A. Swanson.The Adult Learner: The Definitive Classic in Adult Education and Human Resource Development. $5^{\text {th }}$ ed. Houston: Gulf Publishing Co., 1998.

McGuinness, Mike. 'Friday Night and the Gates are Low: Popular music and its relationship(s) to Sport'. In Sporting Sounds: Relationships between Sport and Music, eds. Anthony Bateman and John Bale, 179-192. Abingdon: Routledge, 2008.

Mortimer, Ian. 'The Art of History'. Historically Speaking: The Bulletin of the Historical Society 11, no.3 (June 2010): 12-15.

Palmer, Clive. ed. The Sporting Image: Sports poetry and creative writing. Preston: Centre for Research Informed Teaching, University of Central Lancashire, 2009.

Palmer, Clive. ed. The Sporting Image: What If? An anthology of creative writing based upon real-life events in sport. Preston: SSTO Publications, 2010.

Palmer, Clive. ed. The Sporting Image: The abstraction of form in Sport. Preston: SSTO Publications, 2011.

Palmer, Clive and Paul Gray, 'Adventure into Escapism - if you have the time'. In The Sporting Image: The abstraction of form, ed. Clive Palmer, 136-145. Preston: SSTO Publications, 2011.

Pampel, Fred C. Drugs and Sport. New York: Facts on File Inc., 2007.

Porter, Dilwyn. 'Review Essay: Sports History and Modern British History'. Sport in History 31, no. 2 (2011): 180-196.

Roberts, Michael. 'Sport, religion and division in Northern Ireland: a personal story'. In The Sporting Image: The abstraction of form, ed. Clive Palmer, 98-101. Preston: SSTO Publications, 2011.

Shuart, Joshua A. 'The Media Dichotomy of Sports Heroes and Sport Celebrities: The marketing of professional women's tennis players'. In Proceedings of the 2003 Northeastern Recreation Research Symposium, 145-151. Newtown Square, PA: USDA Forest Service, 2004.

Sugden, John. 'Belfast United: Encouraging cross-community relations through sport in Northern Ireland', Journal of Sport and Social Issues 15, no. 3 (1991): 5980 .

Tatehata, Risa. 'Outrun by the truth and reality'. In The Sporting Image: The abstraction of form, ed. Clive Palmer, 90-93. Preston: SSTO Publications, 2011.

Thompson, Jack. 'Bolt from the darkness'. In The Sporting Image: The abstraction of form ed. Clive Palmer, 86-89. Preston: SSTO Publications, 2011.

Tomlinson, Alan. 'Taking the (Sea)Biscuit?: Sensory and Autobiographical Responses to Hans Ulrich Gumrecht's In Praise of Beauty', Sport in History 28, no.1 (2008): 151-159.

Watson, Patrick. 'Grass Roots'. In The Sporting Image: The abstraction of form, ed. Clive Palmer, 94-97. Preston: SSTO Publications, 2011. 
